Research Paper

\title{
Dexamethasone Down-regulates Osteocalcin in Bone Cells through Leptin Pathway
}

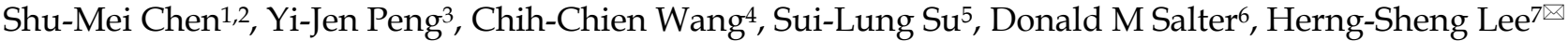 \\ 1. Department of Pathology and Laboratory Medicine, Kaohsiung Veterans General Hospital, Kaohsiung, Taiwan, ROC. \\ 2. Division of Nephrology, Department of Internal Medicine, Tri-Service General Hospital, Taipei, Taiwan, ROC. \\ 3. Department of Pathology, Tri-Service General Hospital, National Defense Medical Center, Taipei, Taiwan, ROC \\ 4. Department of Orthopedics, Taipei Medical University Hospital, Taipei, Taiwan, ROC. \\ 5. School of Public Health, National Defense Medical Center, Taipei, Taiwan, ROC. \\ 6. Centre for Genomic and Molecular Medicine, IGMM, University of Edinburgh, Edinburgh, UK \\ 7. Department of Pathology and Laboratory Medicine, Kaohsiung Veterans General Hospital, Kaohsiung, Taiwan, ROC.
}

$\square$ Corresponding author: Dr. H.S. Lee, Department of Pathology and Laboratory Medicine, Kaohsiung Veterans General Hospital, No.386, Dazhong 1st Rd., Zuoying Dist., Kaohsiung City 81362, Taiwan (R.O.C.) Tel: 886-7-3422121ext.8161; Fax: 886-7-3422288; E-mail: hlee@vghks.gov.tw

(c) Ivyspring International Publisher. This is an open access article distributed under the terms of the Creative Commons Attribution (CC BY-NC) license (https://creativecommons.org/licenses/by-nc/4.0/). See http://ivyspring.com/terms for full terms and conditions.

Received: 2017.07.12; Accepted: 2018.01.05; Published: 2018.03.08

\begin{abstract}
Glucocorticoid therapy, especially at higher doses, is associated with significant adverse side effects including osteoporosis. Leptin, secreted from adipose tissue, has diverse effects on bone tissue regulation. As glucocorticoids stimulate leptin synthesis and secretion directly in adipose tissue we hypothesised that dexamethasone (DEX) induced osteoporosis may, in part, be mediated by an osteoblast dependent leptin-leptin receptor pathway. Human bone cells expressed leptin and leptin receptors (Ob-Ra and Ob-Rb). DEX increased leptin, Ob-Ra and Ob-Rb expression in a dose-dependent manner while decreasing expression of osteocalcin. In the presence of leptin, Cbfal and osteonectin expression showed no significant change, whereas osteocalcin expression was decreased. Recombinant human quadruple antagonist leptin suppressed DEX-induced osteocalcin downregulation. The signaling pathway involved up-regulation of JAK2. In conclusion, upregulation of leptin and $\mathrm{Ob}-\mathrm{Rb}$ in human bone cells by DEX is associated with down-regulation of osteocalcin expression. The down regulation of osteocalcin by DEX was partially through a leptin autocrine/paracrine loop. Adverse effects of DEX on the skeleton may be modified by targeting leptin signaling pathways.
\end{abstract}

Key words: osteocalcin downregulation, dexamethasone, osteoblast

\section{Introduction}

Glucocorticoids are important endocrine regulators of a wide range of cardiovascular, immunologic and metabolic functions postnatally and have multiple roles in development. Glucocorticoids bind to the cytoplasmic glucocorticoid receptor (GR) that dimerizes and translocates to the nucleus and binds to specific glucocorticoid response elements (GRE) [1]. Synthetic glucocorticoids such as prednisone, prednisolone, methylprednisone acetate and dexamethasone are used widely for treatment of inflammatory diseases including asthma, inflammatory bowel disease, and rheumatoid arthritis [2]. Treatment, especially at higher doses, is however associated with significant adverse side effects including osteoporosis $[3,4]$.

Glucocorticoid induced osteoporosis, in common with other forms of osteoporosis such as that resulting from gonadal insufficiency and high intake of alcohol, is characterized by loss of bone mass and deterioration of the microarchitectural bone structure leading to an increased susceptibility to fractures [5]. Glucocorticoids have direct effects on osteoblast, osteocyte, and osteoclast function resulting in reduced bone remodeling and diminished repair of microdamage to bone. In addition to the direct effects on bone cells, glucocorticoids also have effects on the 
intestine, kidneys, gonads, and probably parathyroid glands, which may contribute to osteoporosis [6].

Leptin secreted from white adipocytes is implicated in the regulation of food intake and energy expenditure in rodents and humans [7]. It binds to the leptin receptor $(\mathrm{Ob}-\mathrm{R})$ which is expressed as several different isoforms [8]. Leptins and leptin receptors have now been shown to be expressed in a number of organs and tissues in addition to adipose tissue $[9,10]$. Leptins have diverse effects on bone tissue regulation with leptin receptor mutations [11]. The predominant effect of leptins on bone metabolism appears to be through the hypothalamus by activation of the sympathetic nervous system [12]. Nevertheless, evidence of a likely direct effect in bone appears likely as leptin induce bone growth and formation [13]. As glucocorticoids stimulate leptin synthesis and secretion directly in adipose tissue [14, 15] we hypothesised that glucocorticoid induced osteoporosis may, in part, be mediated by an osteoblast dependent leptin-leptin receptor pathway.

\section{Materials and Methods}

\section{Materials}

Dexamethasone (DEX) was purchased from Sigma-Aldrich Inc. (Steinheim, Germany). Recombinant human leptin/OB was purchased from R\&D Systems Inc. (Minneapolis, MN, USA). The leptin antagonist, recombinant human leptin quadruple mutant (LQM), was obtained from RayBiotech, Inc. (Norcross, GA, USA).

\section{Human bone cell (HBC) isolation and culture}

Bone samples were from surgical discard tissue obtained, with consent, at knee joint arthroplasty from Taiwanese patients with osteoarthritis (OA) $(n=12$, mean age 69.5 years, range 58-83 years). All procedures were reviewed and approved by an institutional human research committee (TMU-JIRB No.201305003). Cortical and subchondral bone fragments were minced, incubated in antimicrobial solution for $4 \mathrm{~h}$ at room temperature, and washed with phosphate-buffered saline (PBS, $\mathrm{pH}$ 7.4) by vortex vigorously to remove fatty components. Bone fragments were maintained in modified McCoy's 5A medium (Gibco, Carlsbad, CA, USA) supplemented with 10\% fetal bovine serum (FBS) (Gibco), 100 $\mathrm{IU} / \mathrm{mL}$ penicillin (Gibco) and $100 \mu \mathrm{g} / \mathrm{mL}$ streptomycin (Gibco). Initial bone cultures were established in petri dishes (Orange Scientific, Braine-I'Alleud, Belgium) before passage into tissue culture flasks (Orange Scientific). Cell populations grown from these bone tissues demonstrated osteoblast-like characteristics with production of alkaline phosphatase. These cells showed no immunoreactivity with an anti-S100 antibody (DakoCytomation, Glostrup, Denmark) excluding growth of adipocytes (data not shown). Cells between passages 3 to 5 were used [16].

HBCs were seeded at $1 \times 10^{5}$ cells/dish and grown as a monolayer for 5 days in $55 \mathrm{~mm}$ tissue culture Petri dishes. Cells were washed with sterile PBS twice, placed in serum-free media for $2 \mathrm{hrs}$, and then co-incubated with $0,1,10$, and/or $100 \mathrm{nM}$ of dexamethasone at $37^{\circ} \mathrm{C}$ for $24 \mathrm{hrs}$. Leptin $(20 \mathrm{ng} / \mathrm{mL})$ and the leptin antagonist LQM $(500 \mathrm{ng} / \mathrm{mL})$ were also used in the functional studies as stated in appropriate experiments. Controls were cultures in serum-free media incubated for the same time periods.

\section{Immunofluorescence}

Cells were cultured at a concentration of $1 \times 10^{5}$ as a monolayer for 5 days in $55 \mathrm{~mm}$ tissue culture Petri dishes. The cells were washed with $5 \mathrm{ml} \mathrm{TBS}$ and then fixed using $2 \mathrm{ml}$ of a 1:1 methanol/acetone mixture per dish for $20 \mathrm{~min}$ at $-20^{\circ} \mathrm{C}$ before further washing with PBS. The cells were then incubated sequentially with primary antibody overnight at $4^{\circ} \mathrm{C}$. The antibodies used were polyclonal anti-leptin (1:10 dilution) (Upstate, Temecula, CA, USA) and monoclonal anti-Ob-R (1:100) (Santa Cruz Biotechnology, Inc., CA, USA) antibodies. Following washing in PBS cells were incubated for $2 \mathrm{~h}$ in darkness with goat-anti-rabbit or goat-anti-mouse IgG conjugated with fluorescein (1:50) (Jackson Immunoresearch Laboratories, Inc., PA, USA), washed again and mounted in buffered glycerin before viewing by fluorescence microscopy (Olympus). Negative controls without primary antibodies were performed for each test.

\section{Reverse transcription-polymerase chain reaction (RT-PCR)}

Total RNA was isolated from cultures of HBC using easy-BLUETM Total RNA Extraction Kit (iNtRON Biotechnology, Gyeonggi-do, Korea). RT-PCR protocol has been described previously from our laboratory [17]. Specific primers and amplifying conditions were shown in Table 1. All PCR products were size fractionated by $1.5 \%$ agarose gel electrophoresis, and DNA bands were visualized by staining the gel with $0.1 \mu \mathrm{g} / \mathrm{ml}$ ethidium bromide.

\section{Western blotting and ELISA}

Following stimulation, cells were immediately washed with sterile PBS and protein extracted using the CNMCS compartmental protein extraction kit according to the manufacturer's instructions (Biochain Institute, Inc., Hayward, CA, USA). In some 
experiments cells were lysed in situ with ice-cold lysis buffer containing 1\% Igepal (Sigma), $100 \mu \mathrm{M} \mathrm{Na}_{3} \mathrm{VO}_{4}$, and protease inhibitor cocktail tablet (Roche Diagnostics, Mannheim, Germany) at $4^{\circ} \mathrm{C}$ for $15 \mathrm{~min}$ to obtain whole cell protein. Protein concentration was determined by the Lowry method. Equal amounts of protein $(10 \mu \mathrm{g})$ were loaded onto $7.5 \%$ SDS-polyacrylamide gel and following electrophoresis were transferred to polyvinylidene fluoride (PVDF) membranes (Millipore Immobilon-P, Sigma). Membranes were blocked overnight at $4^{\circ} \mathrm{C}$ with $2 \%$ BSA in TBST $(12.5 \mathrm{mM}$ Tris/ $\mathrm{HCl}, \mathrm{pH} 7.6,137$ $\mathrm{mM} \mathrm{NaCl}, 0.1 \%$ Tween 20). After washing with TBST, blots were incubated at $4^{\circ} \mathrm{C}$ with antibodies against Ob-R (B-3) (1:500 dilution), osteocalcin, JAK2 or phospho-JAK2 (1:1000) (Cell Signaling Technology, Inc., Danvers, MA, USA) diluted in TBST, washed again before incubation with HRP-labeled secondary antibody (1:1000) for $1 \mathrm{~h}$ at room temperature. Membranes were rewashed extensively and binding detected using the Enhanced Chemiluminescence Western blotting detection system, according to the manufacturer's instructions. Tubulin expression as loading control was assessed with the mouse monoclonal antibody Tubulin-alpha Ab-2 (1:10000) (NeoMarkers, Fremont, CA, USA).

For measurement of leptin levels culture supernatants were collected and leptin concentrations were measured by ELISA (R\&D) according to the manufacturer's instructions.

\section{Animal model analysis}

The $\mathrm{db} / \mathrm{db}$ (B6.BKS(D)-Leprdb/J; deficient in leptin receptors) and wild-type (C57BL/6J) male mice at 7 months of age were used [18]. Experiments were

Table 1. Specific primers and amplification conditions.

\begin{tabular}{|c|c|c|c|c|}
\hline Gene & Primers & $\begin{array}{l}\text { No. of } \\
\text { cycles }\end{array}$ & $\begin{array}{l}\text { Annealing } \\
\text { temp }\left({ }^{\circ} \mathrm{C}\right)\end{array}$ & $\begin{array}{l}\text { Product } \\
\text { size (base } \\
\text { pairs) }\end{array}$ \\
\hline Leptin & $\begin{array}{l}\text { F: 5'-GCATTGGGGAACCCTGTG-3' } \\
\text { R: 5'-AGCACCCAGGGCTGAGGT-3' }\end{array}$ & 35 & 58 & 499 \\
\hline Ob-Ra & $\begin{array}{l}\text { F: 5'-TTGTGCCAGTAATTATTTCCTCTT-3' } \\
\text { R: 5'-AGTTGGCACATTGGGTTCAT-3' }\end{array}$ & 30 & 50 & 200 \\
\hline Ob-Rb & $\begin{array}{l}\text { F: 5'-GCTATTTTGGGAAGATGT-3' } \\
\text { R: 5'-TGCCTGGGCCTCTATCTC-3' }\end{array}$ & 40 & 58 & 501 \\
\hline Osteocalcin & $\begin{array}{l}\text { F: 5'-ATGAGAGCCCTCACACTCCTC-3' } \\
\text { R: 5'-CGTAGAAGCGCCGATAGGC-3' }\end{array}$ & 30 & 60 & 291 \\
\hline Osteonectin & $\begin{array}{l}\text { F: 5'-ACATGGGTGGACACGG-3' } \\
\text { R: 5'-CCAACAGCCTAATGTGAA-3' }\end{array}$ & 35 & 52 & 405 \\
\hline C-I & $\begin{array}{l}\text { F: 5'-GATGGATTCCAGTTCGAGTATG-3' } \\
\text { R: 5'-GTTTGGGTTGCTTGTCTGTTTC-3' }\end{array}$ & 30 & 60 & 480 \\
\hline AP & $\begin{array}{l}\text { F: 5'-ACGTGGCTAAGAATGTCATC-3' } \\
\text { R: 5'-CTGGTAGGCGATGTCCTTA-3' }\end{array}$ & 30 & 56 & 476 \\
\hline Cbfa1 & $\begin{array}{l}\text { F: 5'-CCCCACGACAACCGCACCAT-3' } \\
\text { R: 5'-CACTCCGGCCCACAAATC-3' }\end{array}$ & 30 & 64 & 289 \\
\hline GAPDH & $\begin{array}{l}\text { F: 5'-GGTGAAGGTCGGAGTCAACG-3' } \\
\text { R: 5'-CAAAGTTGTCATGGATGACC-3' }\end{array}$ & 25 & 56 & 497 \\
\hline
\end{tabular}

approved by the local Institutional Review Board (IACUC-15-102) and were performed in adherence to the National Institutes of Health Guidelines for the treatment of experimental animals. Fresh bone tissues from mice were collected for primary bone cell cultures which follow the previous HBC protocol. Osteocalcin gene expression levels in bone cells from the $\mathrm{db} / \mathrm{db}$ and wild type mice $(\mathrm{n}=3$ each) treated with either DEX or solvent for $24 \mathrm{~h}$ were determined by real-time PCR. Complementary DNA was produced from osteoblastic mRNA (5 $\mu \mathrm{g})$ using the SuperScript II RNase H- Reverse Transcriptase kit (Invitrogene, Carlsbad, CA). Triplicates from each plate were used. The gene expression was analyzed by Applied Biosystems Step-One system. Primer sequences are as follows: m-osteocalcin, forward 5'-GACCTCACAGA TGCCAAG-3' and reverse 5'-TCACAAGCAGGGTT AAGC-3'; m-GAPDH, forward 5'- TCACCACCATGG AGAAGGC-3' and reverse 5'- GCTAAGCAGTTGGT GGTGCA-3'.

\section{Statistical analysis}

Bands were analyzed using gel documentation system (Bio-Profil, Bio-1D version 99, Viogene, USA). The values were expressed as ratio of the band intensity of the target gene to the internal control glyceraldehyde-3-phosphate dehydrogenase (GAPDH) gene or the target protein to the internal control tubulin. Variance and $P$ values were analyzed by Alphaimager 1220 V5.5 (Alpha Innotech Corporation, San Leandro, CA, USA). A Student's $t$ test was used for statistical comparison between groups. A $P$ value of less than 0.05 was considered statistically significant.

\section{Results}

\section{Expression of leptin and Ob-R in human bone cells}

Leptin and $\mathrm{Ob}-\mathrm{R}$ were shown to be expressed by $\mathrm{HBC}$ in monolayer culture at the protein and gene level by immunofluorescence and RT-PCR respectively (Fig. 1). RT-PCR demonstrated expression of both $\mathrm{Ob}-\mathrm{Rb}$ (long) and $\mathrm{Ob}-\mathrm{Ra}$ (short) forms of $\mathrm{Ob}-\mathrm{R}$.

\section{Effects of leptin on HBC gene expression}

To examine potential effects of leptin on bone homeostasis primary HBC cultures were incubated with leptin peptide and gene expression of Cbfa1 and bone matrix molecules assessed. Following incubation with $20 \mathrm{ng} / \mathrm{ml}$ leptin for 24 hours there was a significant 
decrease, approximately $25 \%$, in osteocalcin gene expression by HBC (Fig. 2). There was no change in phosphatase gene expression under identical Cbfa1, osteonectin, collagen type I, and alkaline conditions.
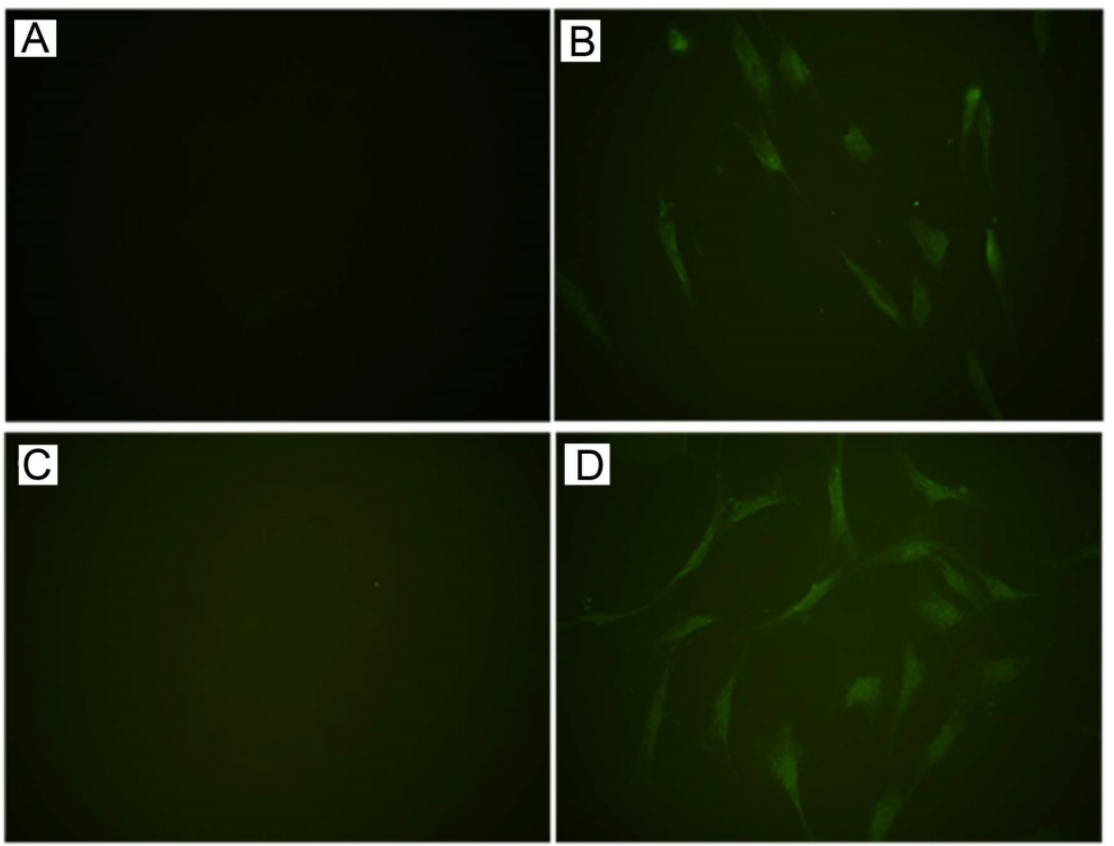

E

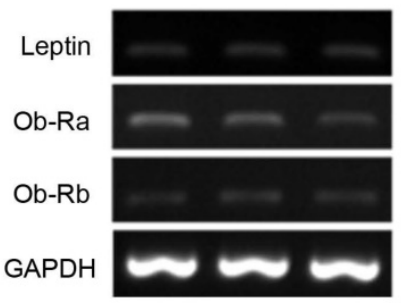

Fig. 1 Expression of leptin and Ob-R in cultures of human bone cells. By immunofluorescence HBC showed expression of lepin (A, negative control; B, anti-leptin antibody) and Ob-R (C, negative control; D, anti-Ob-R antibody). (All figures, 400x). Expression of leptin, Ob-Ra (short form), and Ob-Rb (long form) demonstrated by RT-PCR in three representative samples of HBC derived from different patients $(E)$.

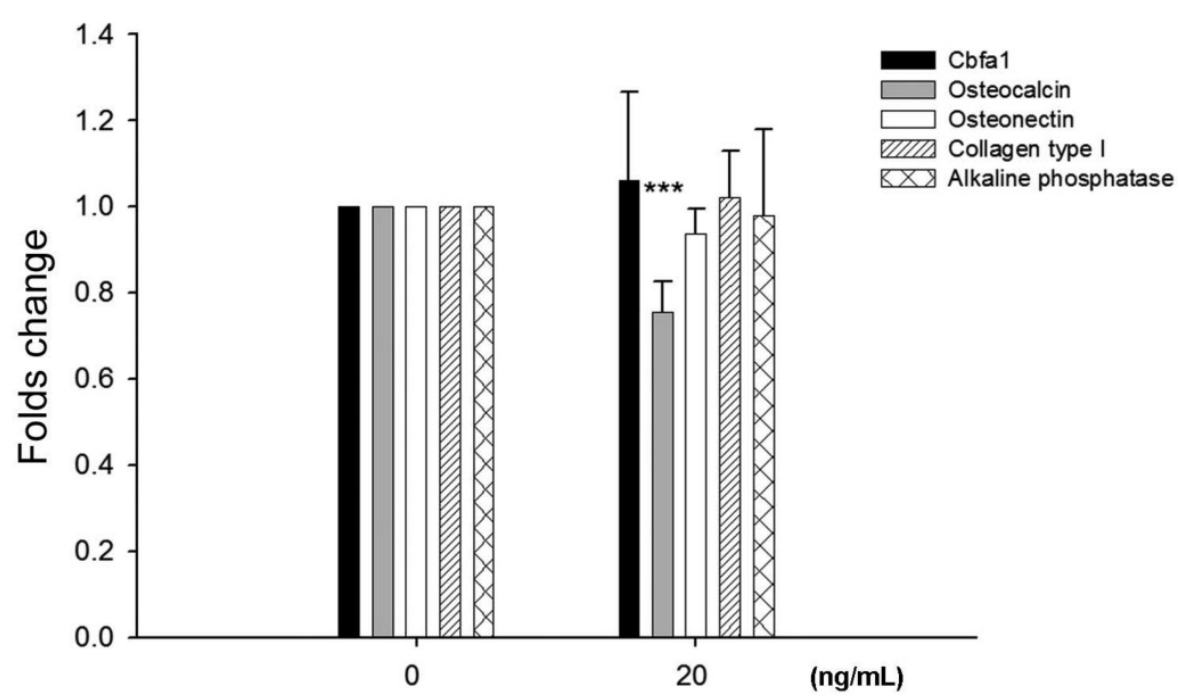

Fig. 2 Effects of leptin on HBC gene expression of cbfal, osteocalcin, osteonectin, collagen type I, and alkaline phosphatase. Incubation of HBC with leptin significantly decreased the osteocalcin expression $(n=5, * * * p=0.0003)$. There was no significant change in expression of the other molecules examined. 


\section{Effects of dexamethasone on HBC}

All HBC cultures expressed alkaline phosphatase and its expression was not influenced by incubation with DEX under the experimental conditions (results not shown). There was a dose-dependent effect of DEX on leptin and Ob-R expression. As shown by semi-quantitative analysis leptin gene expression increased approximately 3.1-fold and 4.9-fold following treatment with 10 and $100 \mathrm{nM}$ of DEX respectively (Fig. 3A). This was associated with increased levels of leptin in the culture media as measured by ELISA (Fig. 3B). Basal levels of leptin were $4.7 \pm 2.0 \mathrm{pg} / \mathrm{mL}$ rising to $14.1 \pm$ $7.9 \mathrm{pg} / \mathrm{mL}$ (3.2-fold increase) and $11.9 \pm 3.8 \mathrm{pg} / \mathrm{mL}$ (2.7-fold) following treatment with 10 and $100 \mathrm{nM}$ of DEX respectively. Ob-R gene expression increased approximately 1.8-fold and 2.2-fold following treatment with 10 and $100 \mathrm{nM}$ of DEX respectively (Fig. 3C). Western blotting demonstrated a 3.3-fold and 5.4-fold increase in $\mathrm{Ob}-\mathrm{R}$ protein expression by HBC following incubation with 10 and $100 \mathrm{nM}$ DEX (Fig. 3D).
A

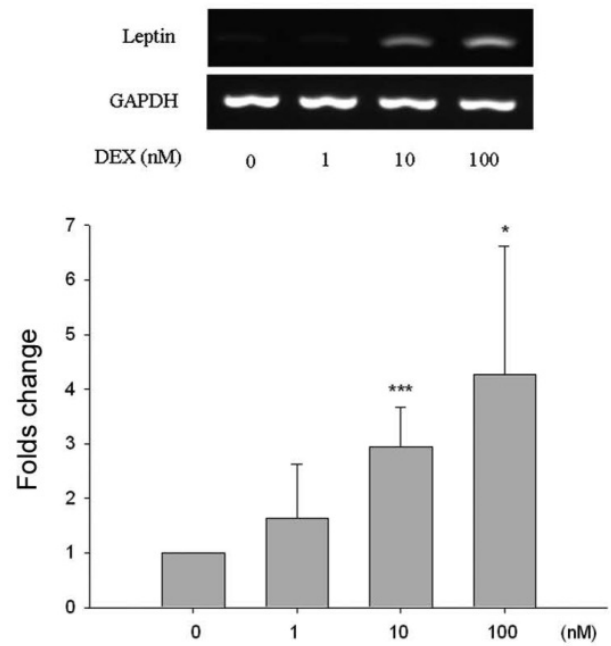

C
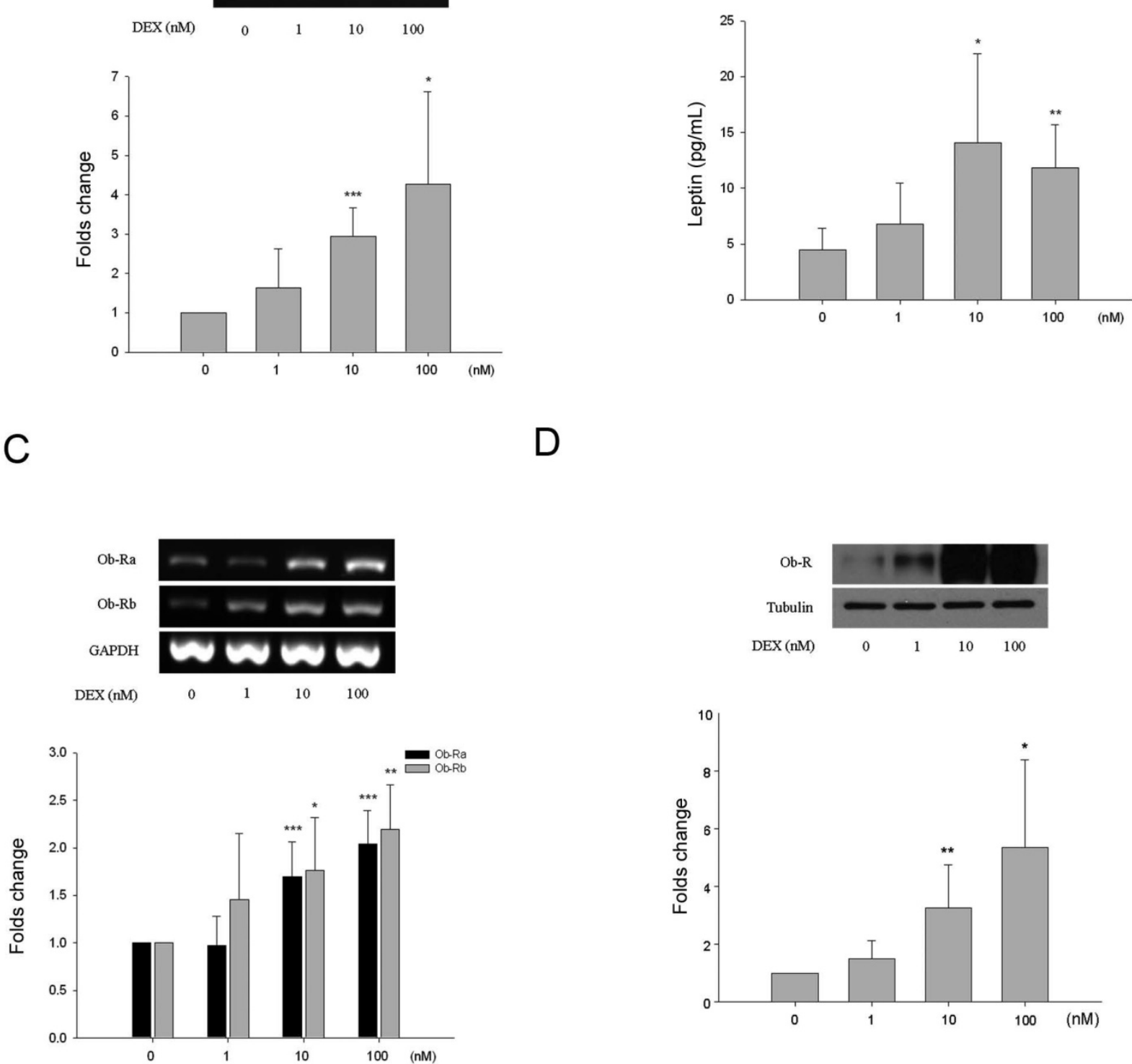

Fig. 3 Effects of dexamethasone (DEX) on HBC. A. Increased leptin RNA levels induced by DEX treatment were identified at the concentrations of 10 and $100 \mathrm{nM}$ $(* \mathrm{p}=0.015, * * \mathrm{p}=0.00035$, respectively). B. By ELISA, release of leptin into culture supernatant increased significantly at $D E X 10$ and $100 \mathrm{nM}(* \mathrm{p}=0.016, * * \mathrm{p}=0.0018$, respectively). C. Increased Ob-R RNA levels induced by DEX treatment were identified at the concentrations of $10 \mathrm{nM}\left(\mathrm{Ob}-\mathrm{Ra} * * * \mathrm{p}=0.0009, \mathrm{Ob}-\mathrm{Rb} *_{\mathrm{p}}=0.002\right)$ and $100 \mathrm{nM}\left(\mathrm{Ob}-\mathrm{Ra}{ }^{* * *} \mathrm{p}=0.0009, \mathrm{Ob}-\mathrm{Rb} *_{\mathrm{p}}=0.019\right)$. D. Significant increase of Ob-R protein at DEX 10 and $100 \mathrm{nM}$ was also seen $\left({ }^{*} \mathrm{p}=0.032,{ }^{*} \mathrm{p}=0.009\right.$, respectively). (All $n=6)$ 


\section{Roles of leptin in DEX regulation of HBC differentiation and bone matrix gene expression.}

As DEX increased leptin and Ob-R expression in bone cells we investigated whether the effects of DEX on HBC differentiation and regulation of bone matrix gene expression was through a leptin dependent mechanism. Collagen type I and alkaline phosphatase gene expression did not alter significantly following treatment with DEX over a concentration range of 1-100 nM (results not shown). There was minimal (9\%) but statistically significant effect of DEX on expression of osteonectin gene expression at the highest concentration whilst Cbfa1 expression was increased by approximately 1.5 -fold and 1.8 -fold following treatment with 10 and $100 \mathrm{nM}$ of DEX (results not shown). DEX had a dose dependent effect on osteocalcin gene expression with a significant decrease seen at both 10 and $100 \mathrm{nM}$ (39\% decrease) concentrations (Fig. 4A). The addition of leptin antagonist (A500, $500 \mathrm{ng} / \mathrm{mL}$ ) blocked the inhibitory effects of DEX on osteocalcin gene expression (Fig. 4B). The osteocalcin protein expression by DEX showed a similar pattern to the gene expression (Fig. $4 \mathrm{C})$.

\section{A}
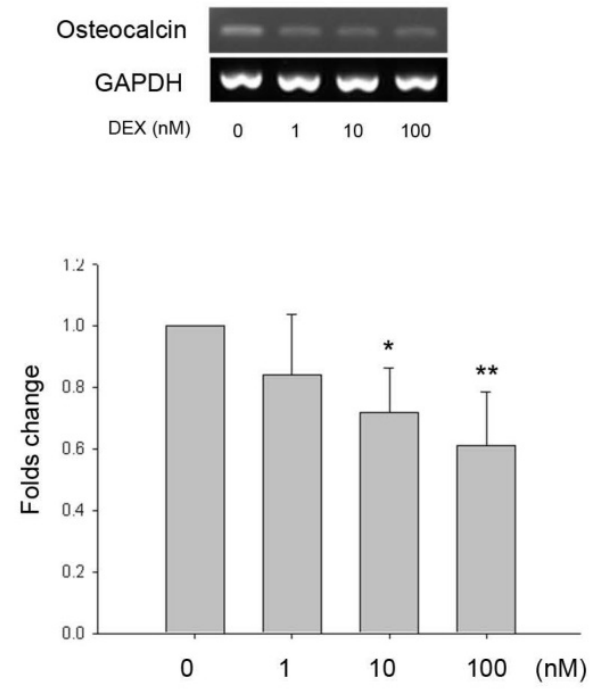

C

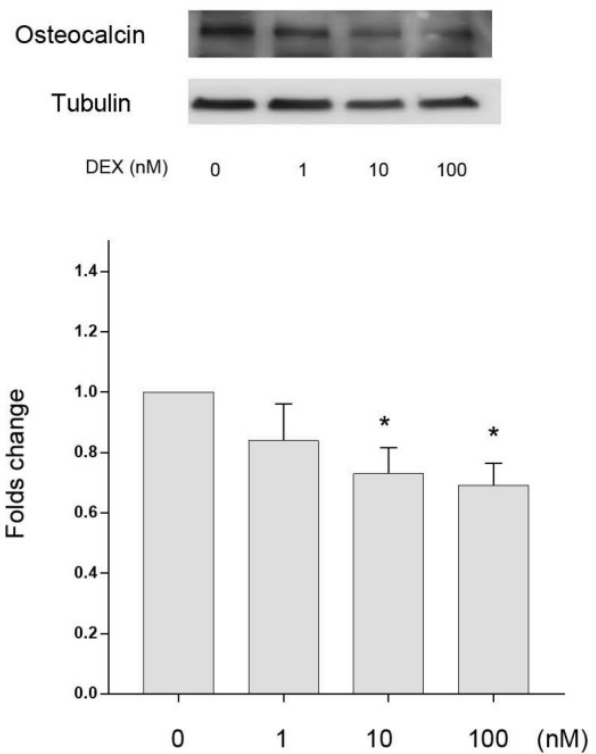

B
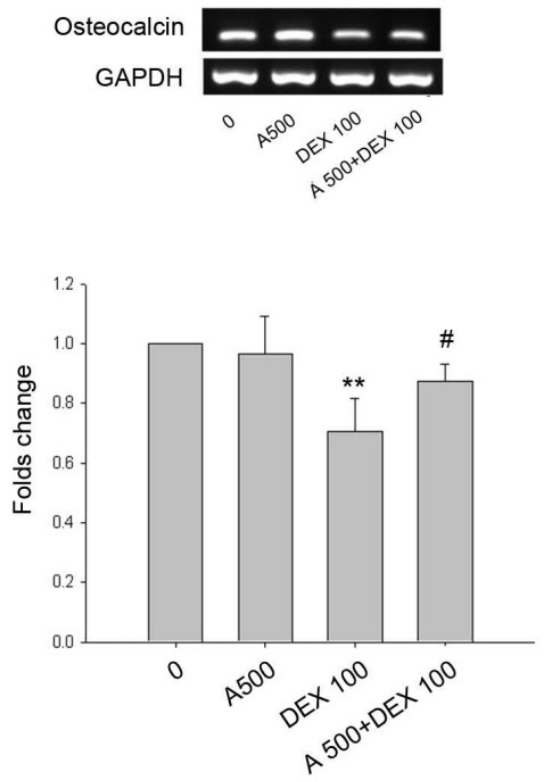
Osteocalcin gene expression by DEX in mouse bone cells

The effect of DEX in the osteocalcin gene expression of primary osteoblastic cells of wild-type and $\mathrm{db} / \mathrm{db}$ mice was tested. Cells treated with $100 \mathrm{nM}$ of DEX showed significant downregulation of osteocalcin in mice of wild type, but not in $\mathrm{db} / \mathrm{db}$ mice (Fig. 5A). The post-receptor leptin signaling molecule to osteocalcin expression may be associated with the protein phosphorylation of JAK2 (Fig. 5B).

A

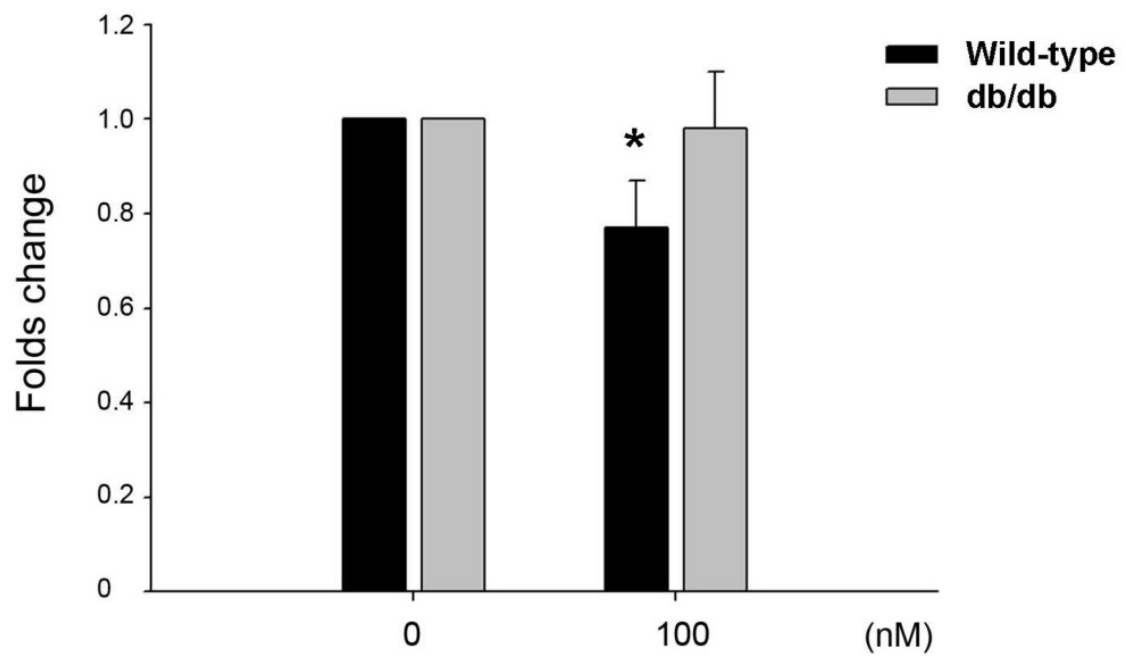

B
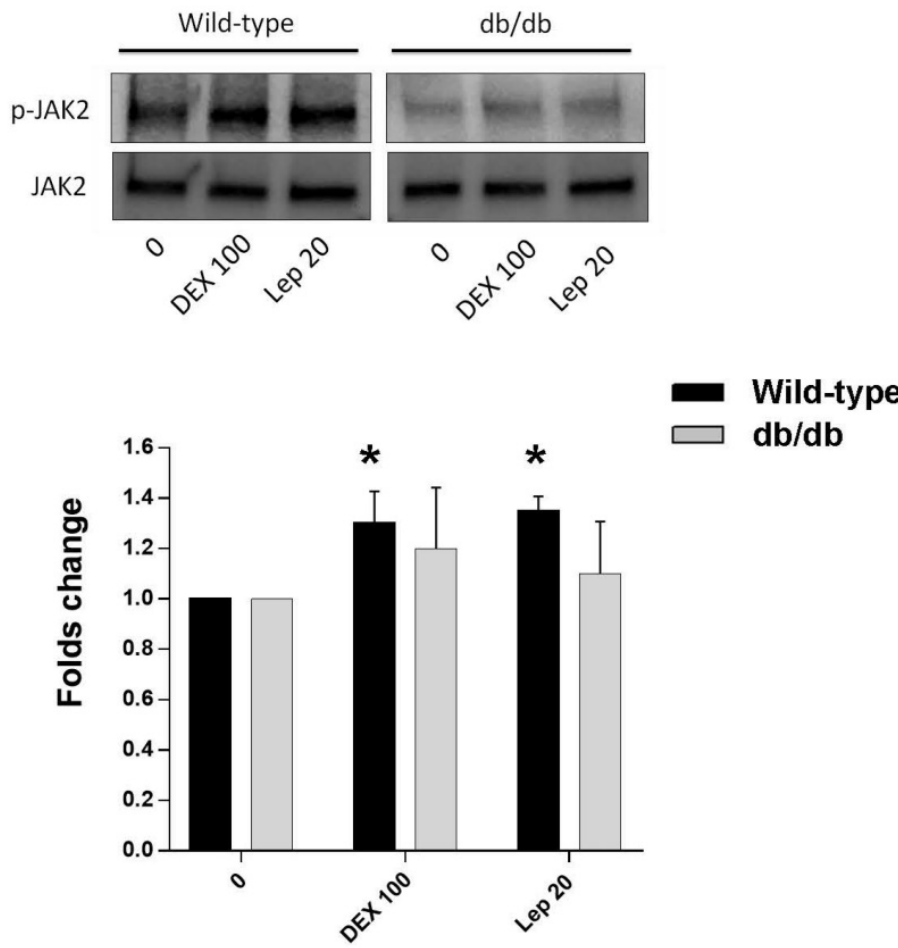

Fig. 5 Animal study in vitro. A. Inhibition of osteocalcin gene expression by DEX in primary osteoblastic cells of wild-type and db/db mice. Cells were treated with $100 \mathrm{nM}$ of DEX for $24 \mathrm{~h}$. Osteocalcin gene expression showed significant decrease in cells from wild-type mice, but not in db/db mice. B. In cells from wild-type mice, the post-receptor signalling molecule was associated with phophorylation of JAK2 in both DEX and leptin (Lep 20 , leptin $20 \mathrm{ng} / \mathrm{mL}$ ) treatment. In cells from $\mathrm{db} / \mathrm{db}$ mice, the tendency of JAK2 phosphorylation was not significant. The data expressed as mean \pm SD. $*$ denotes $P<0.05$ as compared to control cultures without DEX treatment $(n=3)$. 


\section{Discussion}

In the current study we have shown that leptin and $\mathrm{Ob}-\mathrm{R}$ are expressed by $\mathrm{HBC}$ in monolayer culture and leptin decreases osteocalcin gene expression in these cells. DEX increases leptin and Ob-R expression in HBC and effects of DEX on osteocalcin expression which is also confirmed by animal model, appear to be, at least in part, through a novel leptin dependant pathway.

The leptin-leptin receptor pathway has been implicated in the control of a wide range of physiological processes including inflammation, angiogenesis, immune function, haematopoiesis, lipid metabolism, insulin action, and function of the reproductive system $[19,20]$. In pathological settings the leptin-leptin receptor pathway may have roles in cancer cell proliferation, invasion and metastasis [21]. Effects of leptin on bone are complicated with both central and peripheral effects. Genetically leptin-deficient mice, have a decreased trabecular volume in long bones, but an increased vertebral bone mass. Leptin replacement either centrally or peripherally corrects these abnormalities but doses of leptin required centrally are much lower than those needed peripherally indicating the existence of a pathway confined to the brain [22]. Centrally, leptin acting through a central hypothalamic relay inhibits bone mass via the sympathetic nervous system [23]. The leptin dependent regulation of bone mass occurs through via the $\beta 2$-adrenergic receptor as $\beta 2$-adrenergic receptor-null mice have a similar bone phenotype, without metabolic abnormalities. The sympathetic signaling directly affects osteoblasts which express $\beta 2$-adrenergic receptors, controlling proliferation and differentiation through the regulation of AP-1 and genes involved in the molecular clock [24]. Sympathetic stimulation of osteoblasts increases expression of the receptor activator of nuclear factor B ligand (RANKL). The current study confirms reports of leptin and leptin receptor expression in human bone cells indicating roles for peripheral activity in regulation of bone turnover through paracrine and autocrine routes [25] and demonstrates that expression of osteocalcin by bone cells may be regulated by the leptin-leptin receptor pathway.

In the present study, experiments were undertaken using bone cells derived from OA patients rather than normal adult bone and it is unclear whether the findings are unique to OA patients or are more widely applicable. Leptin levels are reported to be elevated in patients, particularly females, with knee OA [26, 27] and synovial fluid leptin concentrations are closely related to the radiographic severity of OA [28]. Although it is accepted that $\mathrm{OA}$ is associated with a high bone mineral density (BMD) and that $\mathrm{OA}$ is generally inversely related to osteoporosis, the relationship between OA and osteoporosis remains controversial. Indeed, the relationship between $\mathrm{OA}$ and osteoporosis may differ by disease site, stage or pathogenetic basis [29, 30]. Furthermore, the pathogenesis of OA in non-obese patients is likely to be different to those of obese individuals where there is a significant contribution to the disease process through the action of pro-inflammatory adipokines such as leptin. Recently, the idea that obesity is protective against fracture is being increasingly questioned with the suggestion now that obesity is a risk factor for certain fractures [31].

Previous studies have shown that treatment of rats with DEX results in decreased bone mineral density and mineralized matrix [32-35]. One of the mechanisms of DEX-induced bone loss is thought to be a direct effect on the osteoblast differentiation [36] via MAPK signalling although glucocorticoid-treated mice also demonstrate the change of apoptosis and autophagy in osteoblasts and osteocytes [37]. DEX could downregulate the osteogenic markers including Runt-related transcription factor 2 (Runx2), alkaline phosphatase and osteocalcin [38]. DEX induces histone deacetylase 6 (HDAC6) expression which binds to glucocorticoid receptor and may inhibit the expression of osteocalcin [39]. However, the mechanism(s) by which DEX influences bone cell differentiation is not fully understood. Glucocorticoids, such as dexamethasone have a marked inhibitory effect on bone formation in vivo. In vitro studies on isolated osteoblasts show both catabolic and anabolic effects although the relevance of the latter is unclear. Pharmacological concentrations of glucocorticoids in vitro inhibit osteoblast proliferation and function whilst increasing osteoblast and osteocyte apoptosis. Similarly dexamethasone decreases proliferation of osteoclast precursors, reduces bone resorption and induces apoptosis in mature osteoclasts, with blunting of osteoclast activity and function having an additional indirect effect of further suppressing osteoblast function [39]. In the present study DEX alters expression of osteoblast differentiation markers inducing a decrease in osteocalcin gene expression and upregulation of Cbfa1 at concentrations where increases in leptin and $\mathrm{Ob}-\mathrm{R}$ expression are also seen. Blockade of the effects of DEX on osteocalcin expression by a leptin antagonist suggests that leptin signalling may contribute to the effects of DEX on bone cells. The post-receptor leptin signaling molecule to osteocalcin expression may be associated 
with the protein phosphorylation of JAK2 which is consistent with other investigations [40].

Leptin has both anabolic and catabolic activity in bone. Leptin promotes bone differentiation in bone mesenchymal stem cells directly [41] whilst increasing RANKL expression by activating $\beta-2$ adrenergic receptors on osteoblasts through the sympathetic nervous system and increasing the activity of osteoclasts in bone resorption [42]. There is increasing interest in the relationship between bone and energy metabolism with leptin and osteocalcin having key roles [43-45]. Whilst many of the potential interactions and effects are a result of endocrine signalling local mechanisms of regulation of osteocalcin and leptin levels in bone may have fine tuning effects. Production of leptin by cells of the osteoblast lineage and autocrine / paracrine activity are likely to play a significant role in both normal and pathological bone turnover including responses to mechanical loading $[45,46]$. Pharmacological regulation of leptin activity may provide an additional means by which primary or secondary abnormalities of bone turnover in a clinical setting can be positively influenced.

\section{Acknowledgments}

This study was supported by grants from the National Science Council and Kaohsiung Veterans General Hospital, Taiwan (NSC97-2320-B-016-009MY3, VGHKS104-100, and VGHKS105-126). We also thank Dr. Chian-Her Lee from Taipei Medical University Hospital for the assistance of sample collection.

\section{Competing Interests}

The authors have declared that no competing interest exists.

\section{References}

1. Cutolo M, Spies CM, Buttgereit F, Paolino S, Pizzorni C. The supplementary therapeutic DMARD role of low-dose glucocorticoids in rheumatoid arthritis. Arthritis Res Ther. 2014; 16 Suppl 2: S1.

2. Mozzini Monteiro T, Ferrera Costa H, Carvalho Vieira G, Rodrigues Salgado PR, da Silva Stiebbe Salvadori MG, de Almeida RN, et al. Anti-asthmatic and anxiolytic effects of Herissantia tiubae, a Brazilian medicinal plant. Immun Inflamm Dis. 2016; 4: 201-12.

3. Rizzoli R, Biver E. Glucocorticoid-induced osteoporosis: who to treat with what agent? Nat Rev Rheumatol. 2015; 11: 98-109.

4. Ko JY, Chuang PC, Ke HJ, Chen YS, Sun YC, Wang FS. MicroRNA-29a mitigates glucocorticoid induction of bone loss and fatty marrow by rescuing Runx2 acetylation. Bone. 2015; 81: 80-8.

5. Wang L, Zhang HY, Gao B, Shi J, Huang Q, Han YH, et al. Tetramethylpyrazine Protects Against Glucocorticoid-Induced Apoptosis by Promoting Autophagy in Mesenchymal Stem Cells and Improves Bone Mass in Glucocorticoid-Induced Osteoporosis Rats. Stem Cells Dev. 2017; 26: 419-30.

6. Wendt E, White GE, Ferry H, Huhn M, Greaves DR, Keshav S. Glucocorticoids Suppress CCR9-Mediated Chemotaxis, Calcium Flux, and Adhesion to MAdCAM-1 in Human T Cells. J Immunol. 2016; 196: 3910-9.

7. Cohen P, Spiegelman BM. Cell biology of fat storage. Mol Biol Cell. 2016; 27: 2523-7.

8. Wasim M, Awan FR, Najam SS, Khan AR, Khan HN. Role of Leptin Deficiency, Inefficiency, and Leptin Receptors in Obesity. Biochem Genet. 2016; 54: 565-72.

9. Zhou J, Lei W, Shen L, Luo HS, Shen ZX. Primary study of leptin and human hepatocellular carcinoma in vitro. World J Gastroenterol. 2008; 14: 2900-4.
10. Wang YJ, Yu HG, Zhou ZH, Guo Q, Wang LJ, Zhang HQ. Leptin Receptor Metabolism Disorder in Primary Chondrocytes from Adolescent Idiopathic Scoliosis Girls. Int J Mol Sci. 2016; 17: pii: E1160.

11. Hannema SE, Wit JM, Houdijk ME, van Haeringen A, Bik EC, Verkerk AJ, et al. Novel Leptin Receptor Mutations Identified in Two Girls with Severe Obesity Are Associated with Increased Bone Mineral Density. Horm Res Paediatr. 2016; 85: 412-20.

12. Sharan K, Yadav VK. Hypothalamic control of bone metabolism. Best Pract Res Clin Endocrinol Metab. 2014; 28: 713-23.

13. Philbrick KA, Wong CP, Branscum AJ, Turner RT, Iwaniec UT. Leptin stimulates bone formation in ob/ob mice at doses having minimal impact on energy metabolism. J Endocrinol. 2017; 232: 461-74.

14. De Blasio MJ, Boije M, Kempster SL, Smith GC, Charnock-Jones DS, Denyer A, et al. Leptin Matures Aspects of Lung Structure and Function in the Ovine Fetus. Endocrinology. 2016; 157: 395-404.

15. Challet E. Keeping circadian time with hormones. Diabetes Obes Metab. 2015; 17 Suppl 1: 76-83.

16. Salter DM, Wallace WH, Robb JE, Caldwell H, Wright MO. Human bone cell hyperpolarization response to cyclical mechanical strain is mediated by an interleukin-1beta autocrine/paracrine loop. J Bone Miner Res. 2000; 15: 1746-55.

17. Huang GS, Tseng $\mathrm{CY}$, Lee $\mathrm{CH}$, Su SL, Lee HS. Effects of (-)-epigallocatechin-3-gallate on cyclooxygenase 2, PGE(2), and IL-8 expression induced by IL-1beta in human synovial fibroblasts. Rheumatol Int. 2010; 30: 1197-203.

18. Chan PC, Hsiao FC, Chang HM, Wabitsch M, Hsieh PS. Importance of adipocyte cyclooxygenase-2 and prostaglandin E2-prostaglandin E receptor 3 signaling in the development of obesity-induced adipose tissue inflammation and insulin resistance. FASEB J. 2016; 30: 2282-97.

19. Perez-Perez A, Sanchez-Jimenez F, Maymo J, Duenas JL, Varone C, Sanchez-Margalet V. Role of leptin in female reproduction. Clin Chem Lab Med. 2015; 53: 15-28.

20. Park HK, Ahima RS. Physiology of leptin: energy homeostasis, neuroendocrine function and metabolism. Metabolism. 2015; 64: 24-34

21. Liu H, Wan D, Pan Z, Cao L, Wu X, Lu Z, et al. Expression and biological significance of leptin, leptin receptor, VEGF, and CD34 in colorectal carcinoma. Cell Biochem Biophys. 2011; 60: 241-4.

22. Wilson JL, Enriori PJ. A talk between fat tissue, gut, pancreas and brain to control body weight. Mol Cell Endocrinol. 2015; 418 Pt 2: 108-19.

23. Turner RT, Dube M, Branscum AJ, Wong CP, Olson DA, Zhong X, et al. Hypothalamic leptin gene therapy reduces body weight without accelerating age-related bone loss. J Endocrinol. 2015; 227: 129-41.

24. Fu L, Patel MS, Bradley A, Wagner EF, Karsenty G. The molecular clock mediates leptin-regulated bone formation. Cell. 2005; 122: 803-15.

25. Mutabaruka MS, Aoulad Aissa M, Delalandre A, Lavigne M, Lajeunesse D. Local leptin production in osteoarthritis subchondral osteoblasts may be responsible for their abnormal phenotypic expression. Arthritis Res Ther. 2010; 12: R20.

26. Scotece M, Mobasheri A. Leptin in osteoarthritis: focus on articular cartilage and chondrocytes. Life Sci 2015; 140: 75-8.

27. Zhang P, Zhong ZH, Yu HT, Liu B. Significance of increased leptin expression in osteoarthritis patients. PLoS One. 2015; 10: e0123224.

28. $\mathrm{Ku} \mathrm{JH}$, Lee CK, Joo BS, An BM, Choi SH, Wang TH, et al. Correlation of synovial fluid leptin concentrations with the severity of osteoarthritis. Clin Rheumatol. 2009; 28: 1431-5

29. Cooper C, Snow S, McAlindon TE, Kellingray S, Stuart B, Coggon D, et al. Risk factors for the incidence and progression of radiographic knee osteoarthritis. Arthritis Rheum 2000; 43: 995-1000.

30. Felson DT, Nevitt MC. Epidemiologic studies for osteoarthritis: new versus conventional study design approaches. Rheum Dis Clin North Am 2004; 30: 783-97.

31. Palermo A, Tuccinardi D, Defeudis G, Watanabe M, D'Onofrio L, Lauria Pantano A, et al. BMI and BMD: The Potential Interplay between Obesity and Bone Fragility. Int J Environ Res Public Health. 2016;13: pii: E544.

32. Kim YU, Karm MH, Cheong Y, Lee J, Kong YG, Kim SH, et al. Effect of Epidural Steroid Injection on Bone Mineral Density in Postmenopausal Women According to Antiosteoporotic Medication Use. Pain Physician. 2016; 19: 389-96.

33. Zhang X, Chen K, Wei B, Liu X, Lei Z, Bai X. Ginsenosides Rg3 attenuates $\begin{array}{lll}\text { glucocorticoid-induced osteoporosis through regulating } & \text { rag }\end{array}$ BMP-2/BMPR1A/Runx2 signaling pathway. Chem Biol Interact. 2016; 256: 188-97.

34. Bozzini C, Champin G, Alippi RM, Bozzini CE. Effect of dexamethasone on mandibular bone biomechanics in rats during the growth phase as assessed by bending test and peripheral quantitative computerized tomography. Acta Odontol Latinoam. 2015; 28: 83-8.

35. Luo SY, Chen JF, Zhong ZG, Lv XH, Yang YJ, Zhang JJ, et al. Salvianolic acid B stimulates osteogenesis in dexamethasone-treated zebrafish larvae. Acta Pharmacol Sin. 2016; 37: 1370-80.

36. Yu W, Zhu C, Xu W, Jiang L, Jiang S. Neuropeptide Y1 Receptor Regulates Glucocorticoid-Induced Inhibition of Osteoblast Differentiation in Murine MC3T3-E1 Cells via ERK Signaling. Int J Mol Sci. 2016; 17: pii: E2150.

37. Komori T. Glucocorticoid Signaling and Bone Biology. Horm Metab Res. 2016; 48: 755-63. 
38. Rimando MG, Wu HH, Liu YA, Lee CW, Kuo SW, Lo YP, et al. Glucocorticoid receptor and Histone deacetylase 6 mediate the differential effect of dexamethasone during osteogenesis of mesenchymal stromal cells (MSCs). Sci Rep. 2016; 6: 37371.

39. Kim HJ, Zhao H, Kitaura H, Bhattacharyya S, Brewer JA, Muglia LJ, et al. Glucocorticoids and the osteoclast. Ann N Y Acad Sci. 2007; 1116: 335-9

40. Hao W, Wang J, Zhang Y, Wang Y, Sun L, Han W. Leptin positively regulates MUC5AC production and secretion induced by interleukin-13 in human bronchial epithelial cells. Biochem Biophys Res Commun. 2017; 493: 979-84

41. Xu JC, Wu GH, Zhou LL, Yang XJ, Liu JT. Leptin improves osteoblast differentiation of human bone marrow stroma stem cells. Eur Rev Med Pharmacol Sci. 2016; 20: 3507-13.

42. Elefteriou F, Ahn JD, Takeda S, Starbuck M, Yang X, Liu X, et al. Leptin regulation of bone resorption by the sympathetic nervous system and CART. Nature. 2005; 434: 514-20

43. Jing D, Luo E, Cai J, Tong S, Zhai M, Shen G, et al. Mechanical Vibration Mitigates the Decrease of Bone Quantity and Bone Quality of Leptin Receptor-Deficient $\mathrm{Db} / \mathrm{Db}$ Mice by Promoting Bone Formation and Inhibiting Bone Resorption. J Bone Miner Res. 2016; 31: 1713-24.

44. Yoo JW, Song CW, Lim HH. Leptin and adiponectin levels in girls with central precocious puberty before and during GnRH agonist treatment. Ann Pediatr Endocrinol Metab. 2016; 21: 199-205.

45. Iwaniec UT, Turner RT. Influence of body weight on bone mass, architecture and turnover. J Endocrinol. 2016; 230: R115-30

46. Kapur S, Amoui M, Kesavan C, Wang X, Mohan S, Baylink DJ, et al. Leptin receptor (Lepr) is a negative modulator of bone mechanosensitivity and genetic variations in Lepr may contribute to the differential osteogenic response to mechanical stimulation in the $\mathrm{C} 57 \mathrm{BL} / 6 \mathrm{~J}$ and $\mathrm{C} 3 \mathrm{H} / \mathrm{HeJ}$ pair of mouse strains. J Biol Chem. 2010; 285: 37607-18. 